\title{
A geografia mítica e real do Atlântico, na visão de Leonardo Torriani
}

The mythical and real geography of the Atlantic, in the vision of Leonardo Torriani

\author{
José Manuel Azevedo e Silva ${ }^{1}$
}

Resumo: Em 1584, Filipe II convidou o arquiteto militar italiano Leonardo Torriani a reorganizar o sistema defensivo das Canárias, ameaçadas pelos corsários e piratas ingleses e franceses. Torriani aí permaneceu até 1593. Não se limitou a cumprir a incumbência régia. Apoiando-se na observação direta e em todo o tipo de informações escritas e orais, deixou-nos o manuscrito 314 da Secção de Reservados da Biblioteca Geral da Universidade de Coimbra, importante fonte documental de natureza histórica, geográfica, cartográfica, arquitetónica, artística e linguística, ilustrada com belíssimas aguarelas.

Palavras-Chaves: Torriani; Canárias; Atlântico mítico e real; arquitetura e história.

\begin{abstract}
In 1584, King Philip II of Portugal invited the Italian militar architect Leonardo Torriani to reorganize the defensive system of the Canary Islands, threatened by English and French privateers and pirates. Torriani remained there until 1593. King Philip II did not limit himself to fulfilling his royal duties. Based on direct observation and on all kinds of written and oral information, he left us the manuscript 314 of the Reserve Section of the General Library of the University of Coimbra, an important documental source of historical, geographical, cartographic, artistic and linguistic nature, illustrated with the most beautiful watercolors.
\end{abstract}

Keywords: Torriani; Canary Islands; mytical and real Atlantic; arquitecture and history.

\footnotetext{
${ }^{1}$ Centro de História da Sociedade e da Cultura, Faculdade de Letras, Universidade de Coimbra (Portugal). ORCID ID: https://orcid. org/0000-0001-8592-7021.
} 


\section{Nota preliminar}

O intento da publicação do manuscrito em italiano de Leonardo Torriani, ${ }^{2}$ que será a matriz deste estudo, exigiu-nos uma preparação prévia e aturada. 0 trabalho de leitura paleográfica do códice italiano e a sua tradução em português levaram-nos a aprofundar os nossos conhecimentos da língua italiana, frequentando, durante três anos, as belíssimas aulas da doutora Rafaella Longobardi Ralha, do Instituto de Estudos Italianos da Faculdade de Letras da Universidade de Coimbra, que nos ajudou, depois, com as dúvidas de tradução de alguns termos ou expressões que nos foram surgindo. A grata recompensa de todo este esforço adveio com a publicação bilingue (português e italiano) do aludido códice (Silva, 1999, passim), versão que citaremos a partir de agora. Vejamos o pensamento de Torriani ao chegar às Canárias, em 1584, durante a sua estada naquele arquipélago e depois dela, até à conclusão do referido códice, em 1594.

Para as antigas civilizações mediterrâneas, nomeadamente para o mundo greco-romano, o Atlântico era um mar truncado (Ferreira, 1999, passim). Esses povos da Antiguidade Clássica conheciam uma faixa atlântica marginando a costa europeia e a parte norte da costa africana, navegavam entre a Escandinávia e o cabo Bojador, entre as Cassitérides (ilhas Bri- tânicas) e as Fortunatae (Canárias), numa navegação de costa à vista ou de costa consabidamente próxima, mas não conheciam a contracosta oceânica a ocidente. É claro que, ao navegarem nas águas do Atlântico Oriental, os mareantes gregos e romanos fixaram no seu espírito e no dos seus povos dois níveis do conhecimento desse mar sem fim: um Atlântico real e um Atlântico imaginário. Vamos tentar captar esse conhecimento dos antigos e confrontá-lo com o dos modernos, partindo da visão quinhentista que o engenheiro militar italiano, ao serviço de Filipe II, Leonardo Torriani expressa no seu manuscrito supracitado.

Convirá esclarecer que Torriani foi incumbido por Filipe II de reorganizar o sistema defensivo das Canárias (restaurar as fortalezas existentes e, se necessário, construir novas, cada vez mais ameaçadas pelos corsários e piratas ingleses e franceses). Aí permaneceu entre 1584 e 1593 e aí trabalhou nos projetos de construção de novas fortificações e na restauração das existentes. Ao mesmo tempo, baseando-se na interpretação dos autores gregos e romanos, recolhendo todo o tipo de informações escritas e orais e apoiando-se na observação direta (revelar-se-á um bom observador), escreveu e deixou-nos o manuscrito já referido, importante fonte documental de natureza histórica, geográfica, cartográfica, ar-

2 Biblioteca Geral da Universidade de Coimbra, Secção de Reservados, Leonardo Torriani, Códice 314. Descrittione et historia del regno de l'isole Canarie gia dette le Fortunatae con il parere delle loro fortificationi, 1594. Está catalogado como um dos tesouros desta biblioteca. 
quitetónica, antropológica, artística e linguística. E não deixemos de apreciar as belíssimas aguarelas, saídas do seu punho. Estamos, sem dúvida, perante um dos últimos humanistas de saber enciclopédico, característico dos grandes homens da Renascença.

\section{As ilhas Afortunadas e o Atlântico mítico-real}

Já habitadas e conhecidas dos antigos, que as consideravam o fim do mundo a ocidente, as ilhas Makáron, dos gregos, ou ilhas Fortunatae, dos romanos, são geralmente identificadas com as modernas Canárias. A real bondade do seu clima e a sua presumível fertilidade, lugar de delícias, onde manava o leite e o mel, fizeram destas ilhas um mítico Paraíso terreal e também o Paraíso celeste, os Campos Elísios da mitologia clássica, onde as almas dos heróis iam repousar, a partir do momento em que as parcas thes cortavam o fio da vida.

Começando por questionar se estas ilhas seriam ou não as verdadeiras Afortunadas, Torriani invoca as referências que delas fizeram Estácio Seboso, Juba, Plínio, Solino, Pompónio Mela, Ptolomeu, Estrabão, Plutarco e muitos outros, para concluir que eram realmente as ilhas Felizes, embora assinalando certos erros dos antigos (Silva, 1999: 7). Porque nesses primeiros tempos elas eram pouco frequentadas pelas longínquas gentes greco-romanas, «os ditos escritores, um após outro, seguiram o que a mentirosa fama ditou aos primeiros que sobre elas fabulosamente escreveram»
(Silva, 1999: 7-8). Concretamente, referindo-se à localização que Plínio fez da ilha de Lançarote, Torriani diz ser «de abandonar a falsa distância que indica de setecentas e cinquenta milhas de Cádis para poente, porque não são mais de setecentas e trinta» (Silva, 1999: 12). Aliás, o nosso autor procura corrigir não só os antigos, mas também os modernos, ao esclarecer que aqueles fazem menção a sete ilhas e estes falam de dez, «mas, na verdade, elas são onze, sete habitadas e cinco desertas» [sic]. Note-se que Torriani também se enganou nas contas, ao indicar um total de 11 , em vez de 12 (sete mais cinco). Quer dizer, os antigos identificaram sete ilhas, que são as maiores e as habitadas (Lançarote, Forteventura, Grã-Canária, Tenerife, Gomera, Ferro e Palma), os modernos referenciaram mais três pequenas não habitadas (Alegranza, Santa Clara e Graciosa) e Torriani acrescentou mais duas (no manuscrito regista a ilha de Lobos, mas esqueceu-se de indicar uma ilhota que, aliás, assinala no Mapa do Caranguejo, com o nome de Roccha del Leste).

Segundo a interpretação de Torriani, no capítulo II, que titula «Do número das Canárias e dos seus nomes», Plínio apenas faz menção a seis Afortunadas, identificadas como as atuais Canárias, do seguinte modo: a Ombrion (Ferro), a Junonia Major (Palma), a Junonia Minor (Gomera), a Capraria (Forteventura), a Nivaria (Tenerife) e a Canaria (Grã-Canária). Como vemos, na interpretação que Torriani faz de Plínio fica estranhamente de fora a ilha de Lançarote. Mas Torriani esclarece que, ao princípio, o 
mesmo autor, com a autoridade de Seboso, «coloca a ilha Capraria juntamente com a Pluviaria, que é a sétima habitada, ou seja, aquela que chamamos Lançarote» (Silva, 1999: 10-11).

Procurando referenciar a sua localização geográfica e sob que signo do zodíaco estavam colocadas, Leonardo Torriani diz que estas ilhas «ficam quase no meio do terceiro clima, frente ao Atlas Menor, e no limite da parte ocidental da Mauritânia». Estendem-se «trezentas e vinte e cinco milhas para poente e cento e setenta de sul para norte, formando o signo celeste do Caranguejo, ao qual estão sujeitas» (Silva, 1999: 23-24).

\section{OVERO FORTVNATE}

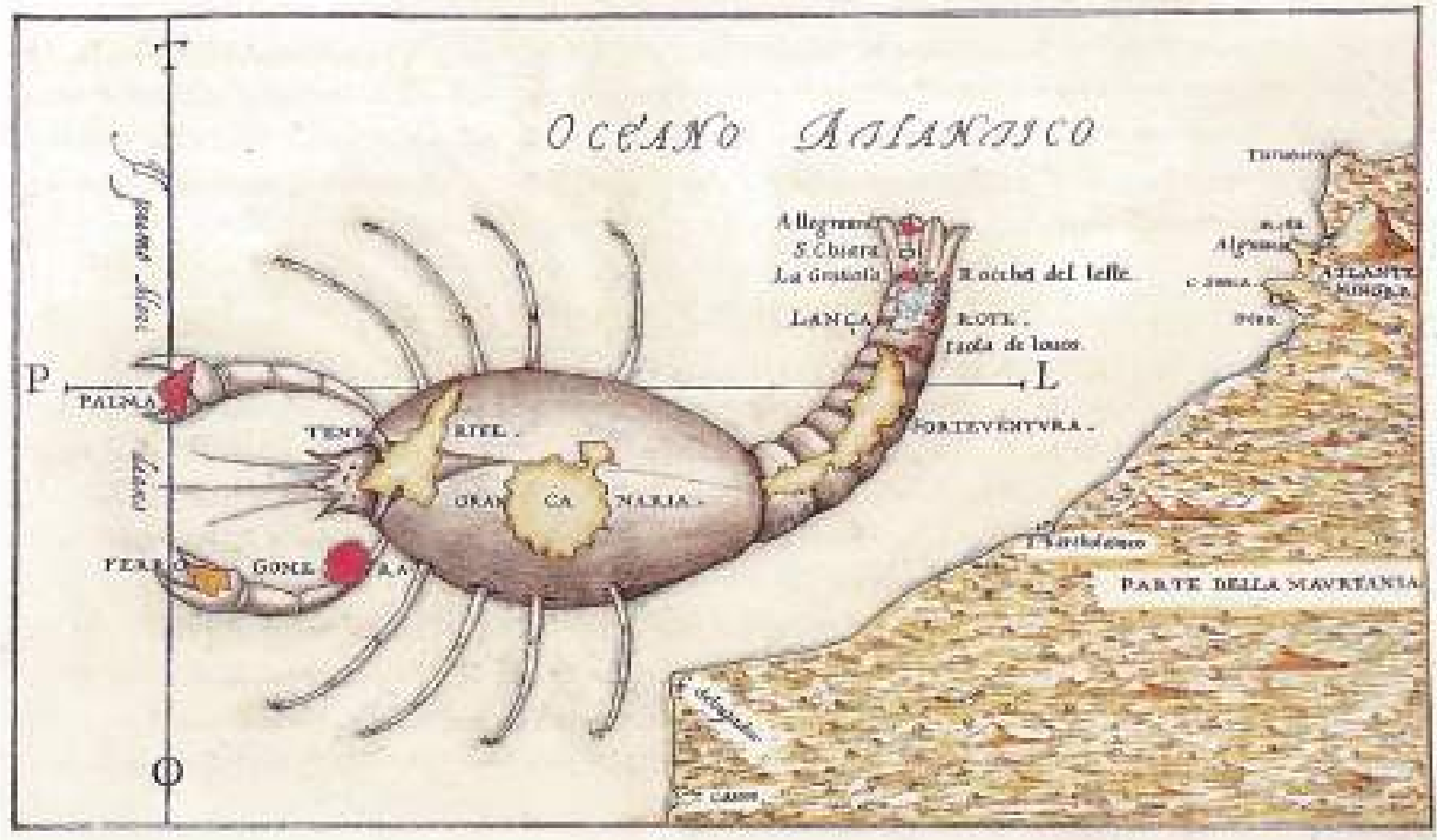

Fig. 1 - Mapa do arquipélago das Canárias, sob o signo do Caranguejo.

Inspirado na influência do signo a que estas ilhas estão sujeitas, o nosso engenheiro militar desenhou, com mestria e imaginação, - mapa das Canárias sobrepondo a figura do caranguejo a todo o arquipélago (fig. 1). Inscreve todas as ilhas nesse mapa e descreve o conjunto do seguinte modo:

Este caranguejo, voltado para onde o Sol se põe, tem na mão direita a Palma, na esquerda o Ferro, no cúbito, um tanto deslocada, a Gomera, na cabeça tem Tenerife (que com dois portos e duas pontas quase forma o rosto com os olhos) e no ventre a Grã-Canária. (Silva, 1999: 24)

E continua: «voltando a cauda para setentrião (que quase em arco acompanha a costa de África), tem a longa Forteventura, a ilha de Lobos,Lançarote e,porúltimo,astrês menores, Graciosa, Santa Clara e Alegranza» (Silva, 1999: 24). Uma vez mais, esqueceu-se de enumerar a ilhota Roccha del Leste, que assinala no mapa a leste da Graciosa. 
Interpretando os autores antigos, Torriani parece pretender sugerir que as Afortunadas foram colocadas por Deus naquelas coordenadas geográficas para colherem todos os benefícios dos elementos e da conjugação astral. Dedica todo o capítulo XLII do seu Códice, intitulado «Da qualidade e costumes dos canários», a demonstrar que os 12 signos do zodíaco têm particular força e domínio sobre toda a Terra habitada, bafejando uns espaços e desprotegendo outros.

Os antigos clássicos dividiram o mundo então conhecido em quatro partes e o signo do zodíaco em quatro triplicidades, fazendo corresponder, pela mesma ordem, cada uma dessas partes a uma triplicidade astral. Ptolomeu, por exemplo, fez essa divisão da Terra pelo cruzamento de duas linhas ortogonais, uma no sentido leste-oeste, na latitude do Mediterrâneo, outra de polo a polo, passando pelo mar Vermelho. Assim, segundo Ptolomeu,

a partir do primeiro meridiano fixo que passa pela mais ocidental destas ilhas, estende-se para levante na distância de 180 graus, passando uma linha pelo Estreito de Gibraltar para levante, equidistante do Equador, e a outra do Polo Ártico ao Antártico, pelo meio do Mar Roxo. (Silva, 1999: 111-112)

Nessa distribuição quadripartida da Terra, os dois quartos orientais compreendiam a Ásia e os dois ocidentais, um a Europa e o outro a África. O primeiro quarto era o oriental meri- dional (Ásia do Sul), da primeira triplicidade do zodíaco: Carneiro, Leão e Sagitário. O segundo quarto, oposto ao primeiro, era o ocidental setentrional (a Europa), da segunda triplicidade: Touro, Virgem e Capricórnio. $\mathrm{O}$ terceiro quarto era o oriental setentrional (Ásia do Norte), da terceira triplicidade: Gémeos, Balança e Aquário. O último, o ocidental meridional (a África e as Fortunatae), da quarta triplicidade: Caranguejo, Escorpião e Peixes. Torriani acrescenta que do signo do Caranguejo é senhora a Lua, de Escorpião Marte, e de Peixes Júpiter (Silva, 1999: 111). Portanto, as Canárias estão sob o domínio da quarta triplicidade, a que corresponde a conjugação da Lua, de Marte e de Júpiter, e sob a influência direta da Lua, porque estão concretamente sob o signo de Caranguejo. E esclarece o nosso autor que, «por a triplicidade do Caranguejo ser feminina, nascem ali muito mais fêmeas que machos e elas têm tal império sobre os homens que bem se pode crer que não é em vão que sobre este zénite passa uma estrela da cabeça de Andrómeda», a qual, segundo os astrólogos, «transporta consigo o cesto de Vénus. Tão-pouco fingiram os poetas que ela nasceu da espuma das ondas fecundíssimas deste Oceano, chamado Pai dos Deuses»(Silva, 1999: 115).

Sem deixar de acreditar na influência dos astros sobre a vida dos humanos, Torriani não retira aos homens o exercício da sua vontade, o seu livre-arbítrio, a capacidade de tomar decisões. Essa sua convicção é apoiada na auto- 
ridade dos antigos, nomeadamente na palavra do príncipe dos astrólogos (refere-se a Ptolomeu), quando disse que «o sábio dominará os astros». Em suma: o homem pode procurar dominar os astros, mas, por mais que o faça, é sempre influenciado por eles, mesmo quando se aplica ao estudo e à tentativa de domínio desses mesmos astros.

Já vimos que as Afortunadas estão sob a influência direta da Lua. Procurando conferir credibilidade ao seu discurso, escreve Torriani no seu Códice: «os filósofos platónicos afirmam que todas as coisas que estão debaixo da órbita da Lua têm o governo e disposição do movimento do céu e do calor e da influência das estrelas» ${ }^{3}$, os quais filósofos, seguindo os astrólogos, nos dão a entender que as inclinações dos mortais, sejam boas ou más, são primeiramente movidas e alteradas pelas causas celestes e que cada um de nós é inclinado àquelas coisas que são da natureza do nosso ascendente e segundo a mistura das virtudes celestes que visam o benigno ou o mau aspeto, deixando a nossa vontade livre para que se possa agarrar, apesar das fortes inclinações, «àquelas coisas que mais sejam do seu agrado, forçando todas as ditas causas naturais, quer com o vício, quer com a virtude» (Silva, 1999: 112).
Como vemos, os homens são livres na ação da sua vontade, mas as suas inclinações não escapam nem à natureza do seu ascendente, nem de serem «movidas e alteradas pelas causas celestes». Embora o arquipélago das Canárias estivesse globalmente sob o signo do Caranguejo, cada uma das suas ilhas tinha influências celestes particulares, incidindo no carácter (vícios e virtudes) e no comportamento dos habitantes. Assim, no dizer de Torriani, os de Lançarote eram ágeis, amorosos e hospitaleiros; os de Forteventura, fortes, fiéis e folgazões; os da Grã-Canária, animosos, prudentes, astutos, ambiciosos e mentirosos; os de Tenerife, ladrões e gentios; os de Gomera, robustos, ágeis, belicosos, pouco atilados, idólatras e melancólicos; os de Ferro, melancólicos (mais do que os das outras ilhas), pacíficos e cobardes; os da Palma, bárbaros, tristes e vis. ${ }^{4}$

Apesar de considerar que os primitivos habitantes destas ilhas eram bisnetos de Noé, netos de Jafet e filhos de Gomero (Silva, 1999: 18 e 23), ao referir-se aos autóctones da Grã-Canária nota a diferença que existia entre estes e os das outras ilhas, nomeadamente no modo de trajar das mulheres e dos homens (Figs. 2 e 3).

${ }^{3}$ Esta teoria pertence à física aristotélica, e não à platónica.

${ }^{4}$ Ver, para cada ilha, os capítulos que tratam dos habitantes e seus costumes. 


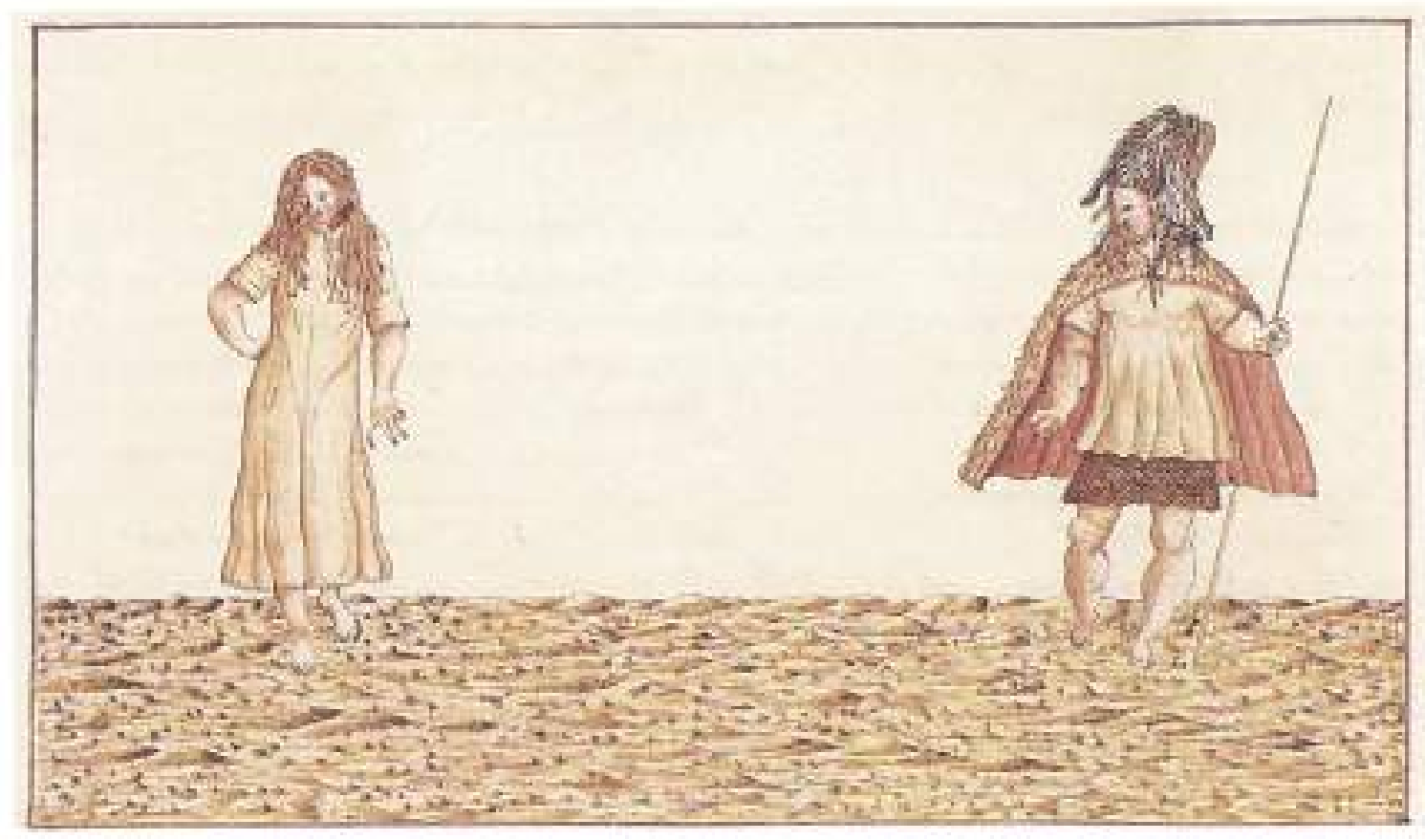

Fig. 2 - Modo de trajar da mulher e do homem da Grã-Canária.
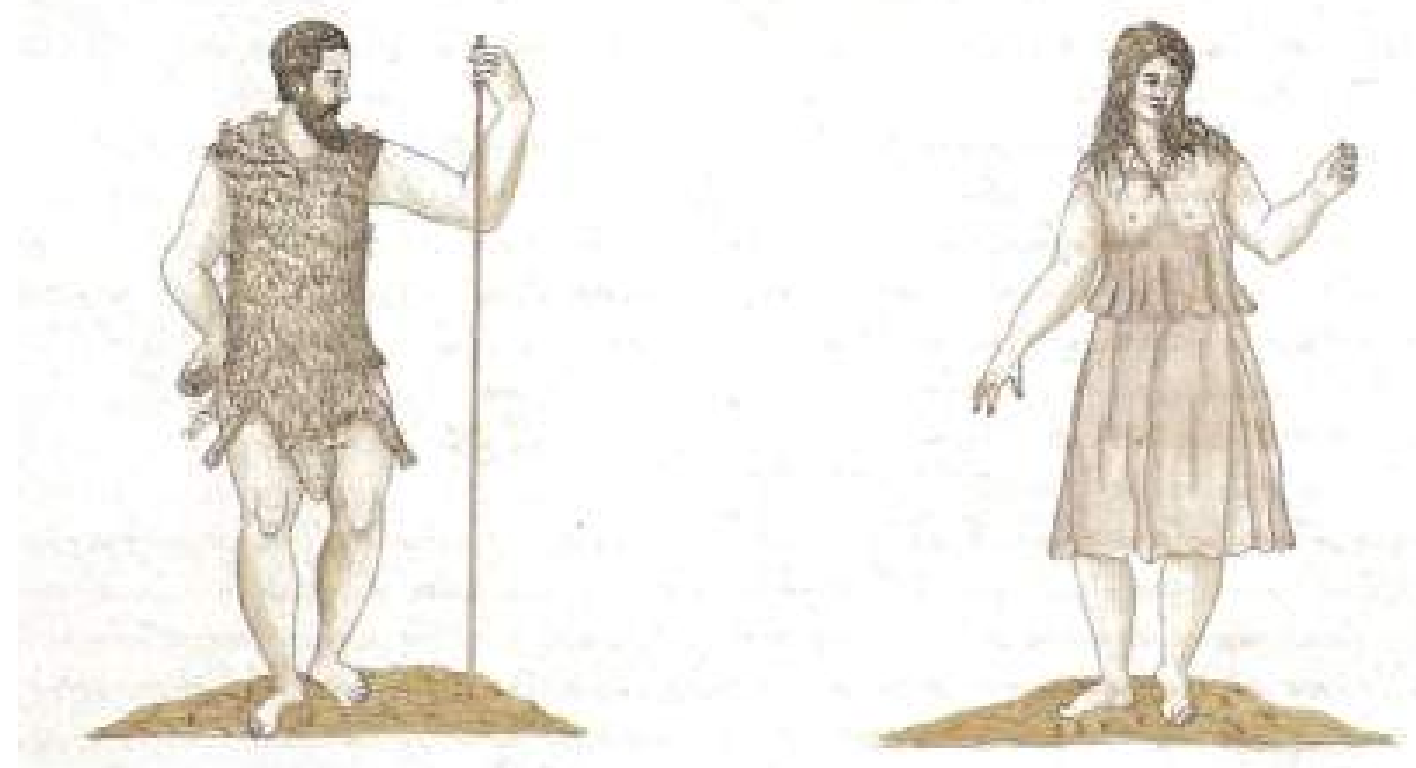

Fig. 3 - Modo de trajar da mulher e do homem da ilha do Ferro.

Questionando por que é que estas ilhas foram chamadas Afortunadas, Torriani assevera, evocando a opinião dos clássicos, que elas foram assim nomeadas pelos antigos poetas, historiadores e geógrafos
[...] pela grandíssima fertilidade e abundância de frutos, pela constância do clima, pelos suaves e húmidos ventos e pela pureza e temperança do ar, das quais Plutarco cria ser tal a humidade que bastava para alimentar suficientemente a todos, sem plantar nem cultivar. (Silva, 1999: 13) 
Por isso, não é de estranhar que os antigos tenham crido serem ali os verdadeiros Campos Elísios, «no fim da Terra então conhecida e na mais calma e tranquila estância». Homero, ao fazer Proteu vaticinar a morte de Agamémnon, pensando que as almas depois da morte dos corpos aqui vinham receber o prémio que em vida mereceram por suas obras, assim disse:

Mas aos Campos Elísios e ao extremo da Terra

Os imortais te enviassem onde está o louro

[Radamanto,

Onde a vida dos homens é facílima:

Em tempo algum há neve ou frio e chuva em [demasia,

Mas sempre o sopro do Zéfiro, fortemente

[sibilante,

O Oceano envia para refrescar os homens.

(Silva, 1999: 14)

O mesmo dirá, por outras palavras, Torcato Tasso, no dizer de Torriani, seu contemporâneo, o segundo Homero, que na Grécia talvez tivesse sido o primeiro. Aludindo àquilo que o príncipe dos poetas cantou e outros escreveram acerca das ilhas Afortunadas, fez falar a Fortuna do seguinte modo:

Ali, nunca em vão floresceram as oliveiras,

E dizia pingar o mel das azinheiras ocas

E escorrer pelas encostas das suas montanhas

[os riachos,

Com águas doces e murmúrio suave:

E zéfiros e orvalhos os raios estivais

Retemperavam de tal maneira que nenhum

[calor vos é pesado;

E aqui pôs os Campos Elísios e as famosas
Estâncias das bem-aventuradas almas.

(Silva, 1999: 14-15)

Ao contrário das Gorgónias das mulheres monstruosas que nelas viviam, das Purpurárias, das Hespérides, das Cassitérides e das Baleares, as Afortunadas eram bafejadas pela «clemência e favor do Céu». Os ventos suaves, as temperaturas amenas, as cantantes águas dos riachos e o benéfico ar marítimo do Atlântico não deixam dúvidas de que estamos no sexto Paraíso terreal, situado pelos antigos no extremo do mundo, a ocidente.

A nosso ver, Torriani é, ao mesmo tempo, um mitófago e um mitófano. Com efeito, por um lado, verbera os antigos e esforça-se por devorar o mito, quando nos vem dizer que eles, os antigos, «erraram tanto nos seus escritos que posteriormente alguns duvidaram serem estas as Ilhas Felizes»; que «os ditos escritores, um após outro, seguiram o que a mentirosa fama ditou aos primeiros que sobre elas fabulosamente escreveram» (cap. I); que, falando do vulcão da ilha da Palma (Fig. 4), «destes incêndios terrestres lemos coisas maravilhosas nos escritores antigos, os quais até o cair de Fáeton querem que tenha sido incêndio natural, depois coberto pela antiguidade com fabuloso véu» (cap. LXIX); que Aristóteles e Alexandre Magno, e muitos outros filósofos, creram, como os poetas, que a zona tórrida era inabitável, contra a opinião de Avicena e a experiência dos modernos» (cap. IV). 


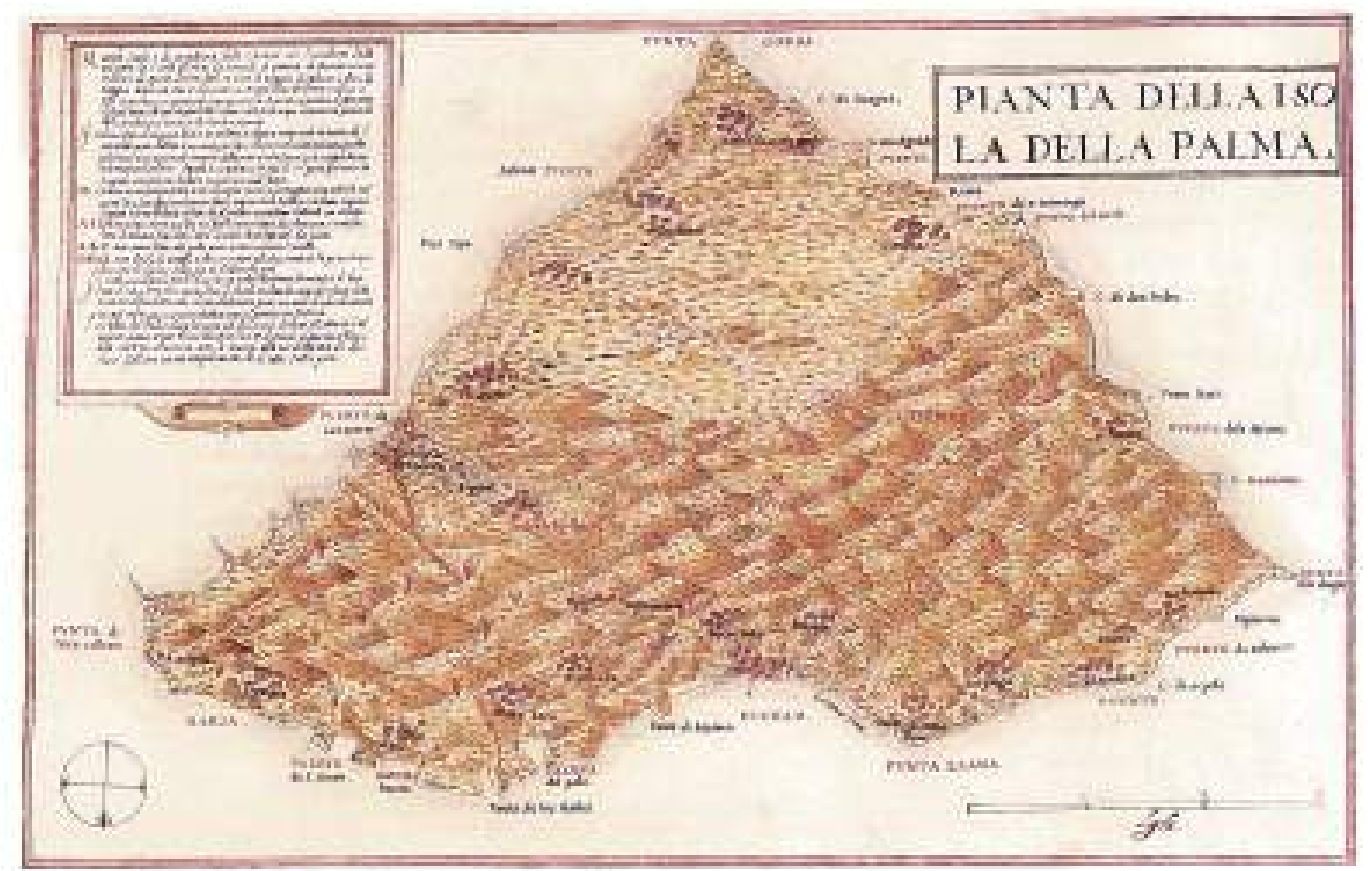

Fig. 4 - Mapa da ilha da Palma, na qual Torriani observou a erupção de um vulcão.

Por outro lado, revela-se um alimentador e um criador de mitos, de fábulas e de teratologias, ao crer e afirmar que, na ilha do Ferro, «a garoa é uma árvore sagrada que destila água e produz chuva» (cap. LXIV); que o beato Maclóvio ressuscitou, em Tenerife, «um gigante, o qual, batizado por ele, contou as penas dos pagãos e dos judeus e, pouco depois, voltou a morrer» (cap. LI); que «os canários viveram sem conhecer nem sentir a doença senão aos cento e vinte e cento e quarenta anos» (cap. XXX); que em 1591 morreram dois homens, «um na Canária, chamado Chiuzzon, de cento e quarenta anos, e outro em Lançarote, chamado Camacho, de cento e trinta e sete anos que também deixou dois irmãos, um de cem anos, outro de oitenta que não demonstram metade da idade» (cap. XLI); que Forteventura tem «carneiros de quatro e até de sete cornos como em Lançarote e alguns deles nascem com cinco pernas, das quais uma thes nasce debaixo da barriga» (cap. XX); que, enfim, havia entre os forteventurinos «altíssimos gigantes, porque, além da memória que deles se conservou, foi encontrado na gruta de uma montanha um cadáver de 22 pés de comprido» (cap. XIX).

Como vemos, para conferir credibilidade aos seus mitos e às suas fábulas teratológicas, Torriani não se coíbe de invocar a autoridade das provas arqueológicas. Nas suas frequentes digressões pela mitologia clássica e pela astrologia (v.g., cap. XLII), apresenta, por vezes, as teorias dos antigos, mas tem dificuldade em decidir pela aceitação ou pela recusa. Dir-se-ia que o peso da autoridade dos antigos the tolhe o raciocínio. Então, como que deixa ao leitor o livre-arbítrio da sua interpretação, ou, noutros casos, prefere refugiar-se na versão bíblica, como é o caso de considerar os habitantes das 
Canárias «bisnetos de Noé, netos de Jafet e filhos de Gomero» (caps. IV e LVIII).

Mesmo quando disserta sobre questões a que pretende conferir carácter científico, como é o caso do vulcanismo, não consegue libertar-se totalmente do peso dos antigos e da explicação mitológica ou sobrenatural. Entre o êxtase e o medo de que se sente possuído, ao presenciar a violenta erupção do vulcão da Palma, em 1585, apaixona-se pelo vulcanismo e esforça-se por procurar a explicação de tais fenómenos telúricos. Dedica-lhes, inteirinho, o mais longo capítulo do Códice (cap. LXIX) e trata constantemente o tema noutras partes do manuscrito, nomeadamente nos capítulos VII,XI,XVIII,XIX e L, onde expende a teoria de que não só o fogo mas também os ventos comprimidos no interior da Terra originam os vulcões e outros movimentos telúricos. É ainda notória esta sua paixão ao manifestar o propósito de aprofundar a explicação da etiologia destes fenómenos, quando nos diz que «a causa disto se dirá no Tratado dos Vulcões que nós, se Deus quiser, daremos à luz» (cap. LXIX), sonho que, tanto quanto se sabe, não conseguiu realizar (rever Fig. 4).

Ressalve-se que, quando se trata do domínio da sua formação específica e do exercício da função de engenheiro militar, Torriani abandona completamente a atitude especulativa e a explicação mítica. Vemos isso nos capítulos que dedica ao sistema defensivo das Canárias, aliás o motivo central da sua estada naquele arquipélago. A sua filosofia de defesa militar assenta na forma como devem ser construídas as fortificações, o que vemos nos três pressupostos que enuncia assim: «trataremos de fortificar estas ilhas, tendo em conta o sítio, a força dos inimigos e o número daqueles que as hão de defender» (cap. XIV). Propõe mesmo ao rei a mudança da Fortaleza de Guanapai e da vila de Teguise para o Arrecife, na ilha de Lançarote, por considerar este sítio mais apropriado quanto à salubridade e às condições de defesa (Fig. 5). 

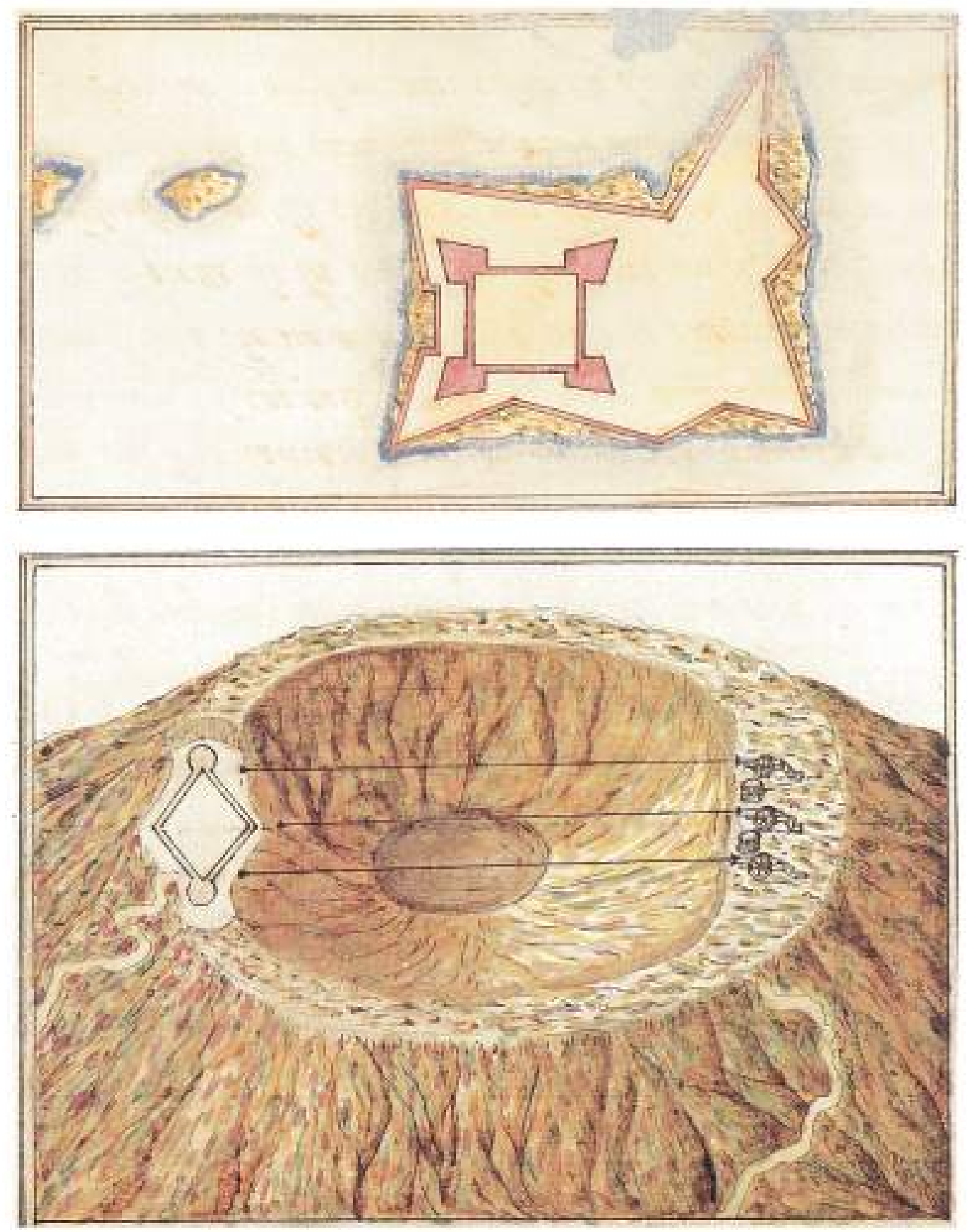

Fig. 5 - Projeto de reedificação da Fortaleza de Guanapay, no Arrecife (em baixo), e planta da mesma, para a qual se propõe mudar a vila de Teguise (em cima), na ilha de Lançarote.

Pelo recurso ao método regressivo, isto é, partindo das modernas Canárias para as antigas Fortunatae, facilmente se conclui não ter este arquipélago feito realmente parte do Império Romano, muito menos dos mundos helénico, fenício ou cartaginês. Não há marcas linguístico-culturais nem vestígios arqueológicos que atestem a presença da romanização nestas ilhas do Atlântico. Não houve, portanto, uma navegação regular e sistemática das antigas civilizações do Mediterrâneo para os mares deste espaço insular, ao contrário do que se sabe ter acontecido na faixa oceânica a norte das Colunas de Hércules, bordejando a costa atlântica da Europa e integrando as ilhas Britânicas. Tal significa que houve navegação, co- 
municação e recolha de informações por parte desses povos da Antiguidade Clássica a respeito destas ilhas, como atestam as referências registadas pelos autores greco-romanos, evocados por Torriani, mas não se processou a sua colonização. Dito de outro modo, navegou-se nestas águas, pode até considerar-se esta faixa do Atlântico Oriental um mar greco-romano, houve conhecimento deste espaço insular, mas não houve interesse na sua integração efetiva, isto é, na fixação das gentes do Mediterrâneo nestas ilhas.

Como refere Leonardo Torriani, Ptolomeu considerou as Afortunadas e o mar que as envolve o limite do mundo romano a ocidente. Por isso, no seu Mapa do Caranguejo, faz passar pela ilha da Palma o primeiro meridiano fixo (Silva,1999: 113), a partir do qual se contavam 180 graus para levante até ao antimeridiano. No capítulo em que se refere a esta ilha, diz ser «assim chamada pela abundância de palmas, é a última das Afortunadas a Ocidente, pelo meio da qual passa o primeiro meridiano fixo, com o qual o alexandrino Ptolomeu começou a descrição da Terra» (Silva, 1999: 173). Pela mesma ilha faz passar uma outra linha, perpendicular ao meridiano de referência, assinalando deste modo no mapa os quatro pontos cardeais: o norte, com a letra "T" (tramontana); o sul, com o "O" (ostro); o este, com o “L” (leste); e o oeste, com o “P” (poente) (rever Fig. 1).

Entre as ilhas que constituem o arquipélago das Afortunadas, Torriani destaca as duas maiores e as mais populosas: a Grã-Canária e Tenerife.

Quanto à Grã-Canária, diz ser «favorecida por particular influência das estrelas». Não admira, pois, que a sua população aumentasse tanto que chegaram a escassear os produtos da terra para se alimentarem (Silva, 1999: 66 e 87). Acrescenta que, em algumas partes da ilha, particularmente nas cercanias da cidade de Telde, os campos «são ricos em açúcar, vinho, trigo, cevada e outros tesouros da terra» (Fig. 6). 

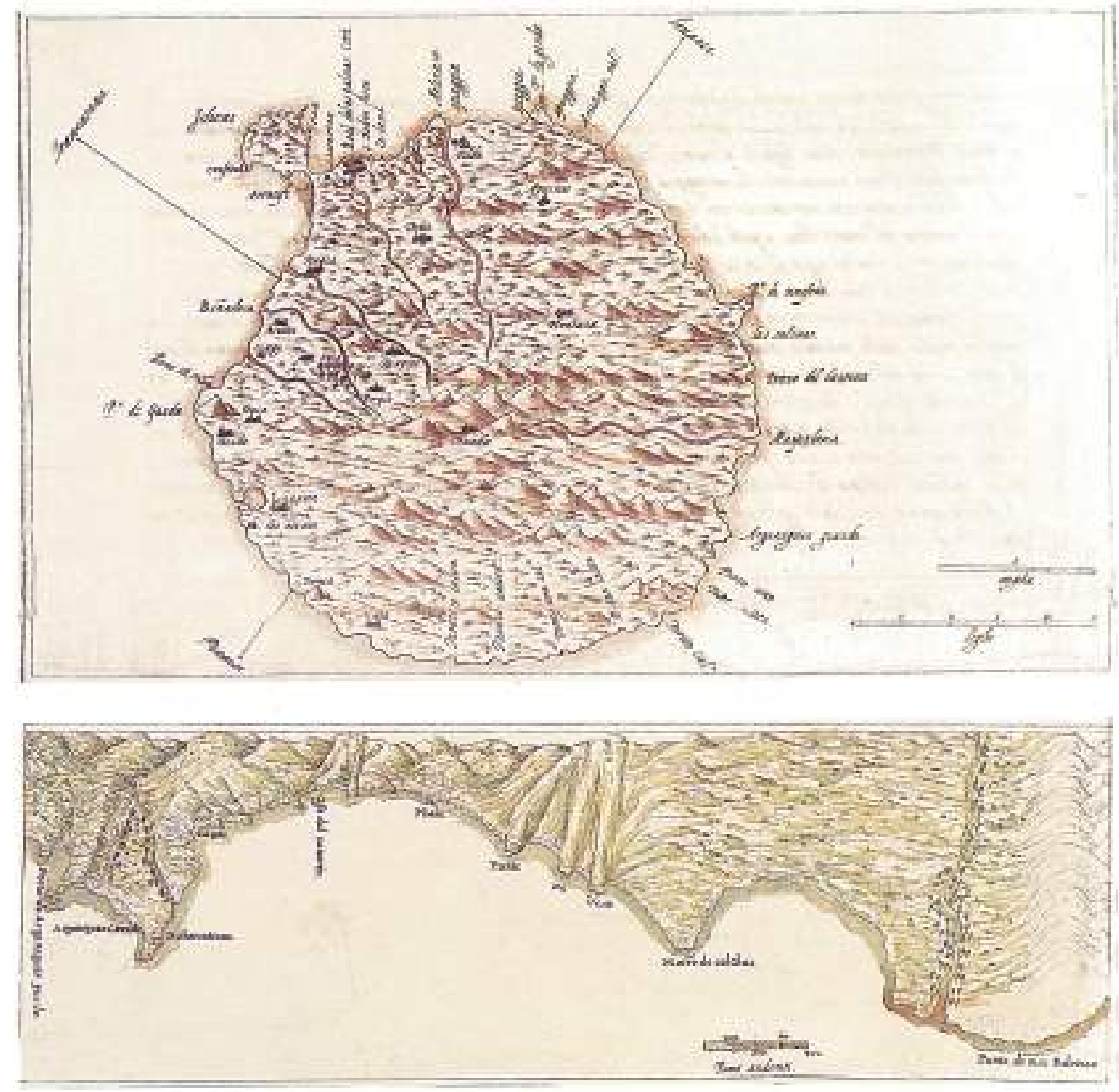

Fig. 6 - Mapa da Grã-Canária e perspetiva da sua costa.

Relativamente a Tenerife, afirma Torriani que «é a maior das Afortunadas e a mais soberba, a qual se situa no meio das outras». Informa ainda que «é, de longe, mais rica que as outras, em açúcar e em vinhos excelentes que são exportados para diversas partes do Mundo». «Tem muito comércio, porque é mais povoada que a Canária e o dobro da Palma. A maior parte da gente é portuguesa, a qual, superando as demais nações espanholas na indústria da agricultura, tem dado a esta ilha maior fertilidade e riqueza» (Silva, 1999: 136).
E continua: «Da banda do Norte, está cheia de belíssimas vilas de 300 e 600 casas cada uma. E tem fertilíssimos terrenos, espessíssimos e altíssimos bosques, o que é coisa de maravilha para a construção de navios e edifícios» (figura 7). Retenha-se a curiosidade de Torriani ao observar que o singular desenvolvimento da «indústria da agricultura» e da demografia da ilha de Tenerife se devia ao facto de a maior parte da gente ser portuguesa, sendo de supor que a maioria desta gente portuguesa era madeirense. 


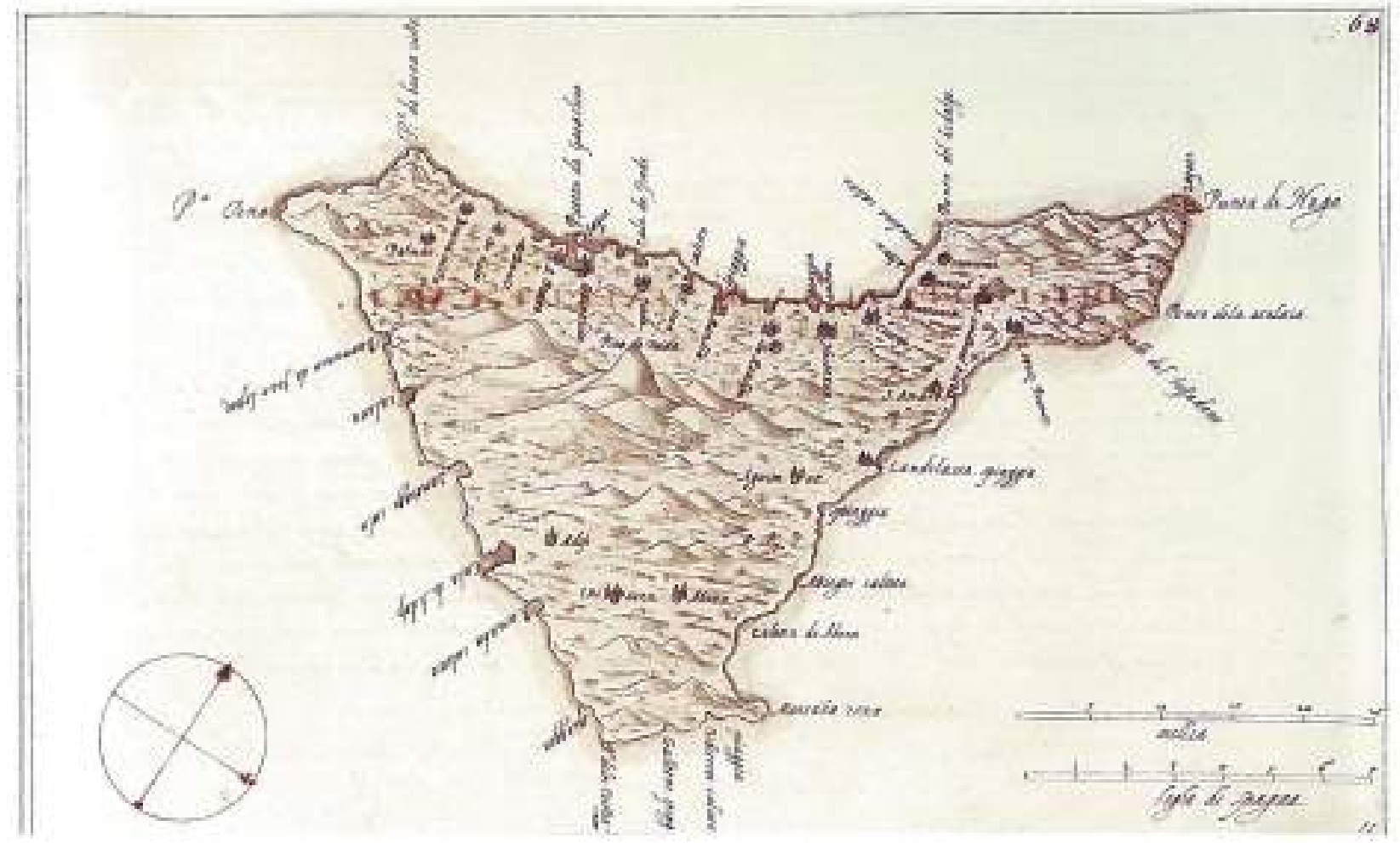

Fig. 7 - Mapa da ilha de Tenerife.

\section{A ilha Antília, ou de São Brandão}

Na sua Aggiunta (Apêndice), Torriani trata dos seguintes temas: da ilha Antília, ou de São Brandão; da descrição do mar Atlântico; da ilha do Porto Santo; da ilha da Madeira; das ilhas Selvagens; e da costa da Berberia. Vejamos.

Evocando informações de vários navegantes que aportaram nas Canárias, Torriani trata, no capítulo I do «Apêndice», «Da Ilha Antília ou de São Brandão que não se encontra». Des- creve com presumível rigor a dita ilha, fazendo-a acompanhar, inclusive, de um mapa que ele próprio elaborou (Fig. 8), atribuindo-lhe, «segundo as mais dignas observações», o comprimento de 264 milhas e a largura de 93 milhas, estendida no sentido norte-sul, entre as latitudes norte de 34 graus e 29 graus e 17 minutos, e localizada pelos 3 graus e 43 minutos oeste do meridiano da Palma, como vimos o primeiro meridiano fixo do mundo greco-romano. 


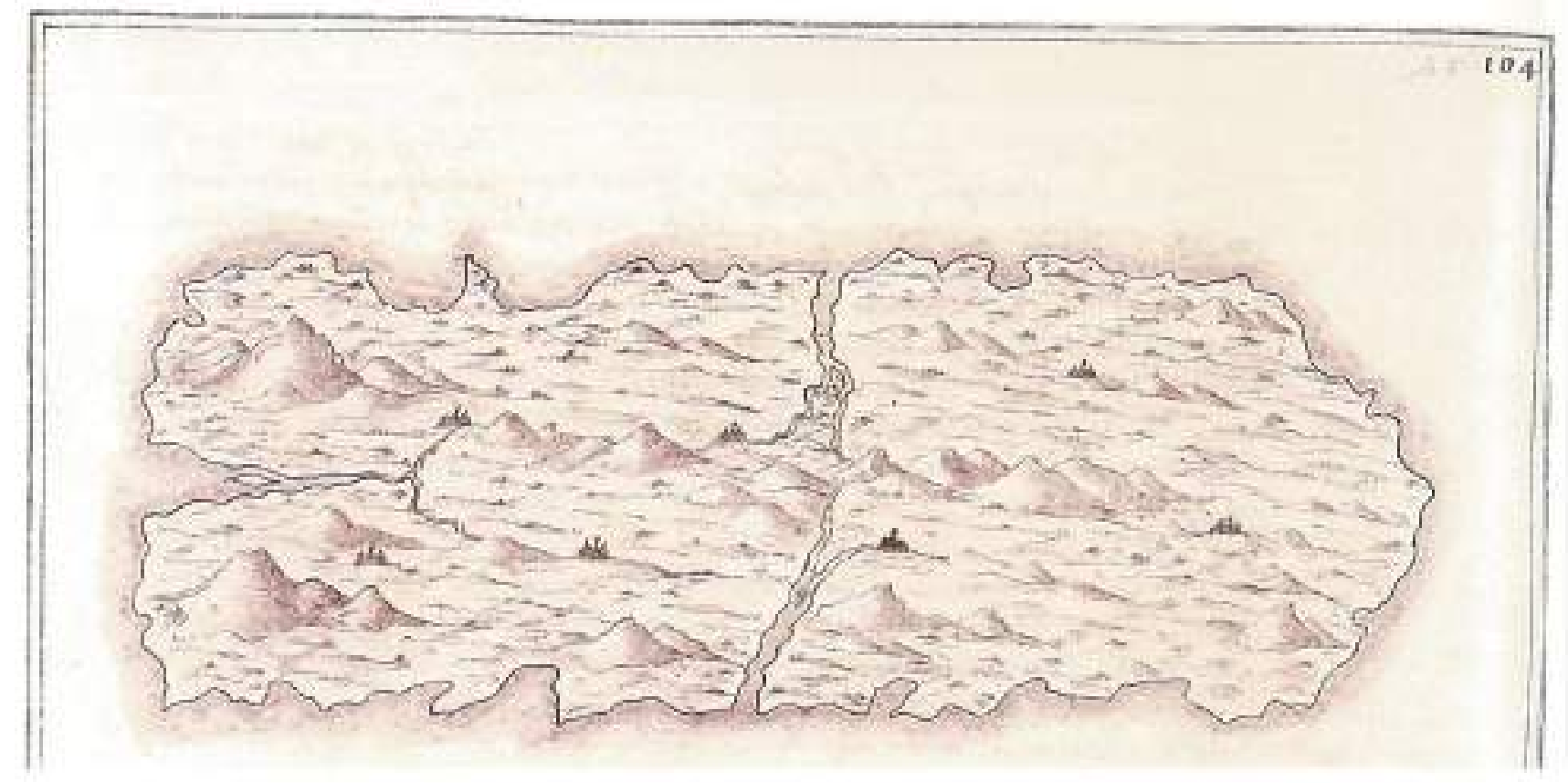

Fig. 8 - Mapa da mítica ilha Antília, ou de São Brandão.

Para ilustrar as suas afirmações, Torriani faz referência a várias viagens, realizadas no século XVI, cujos marinheiros terão avistado ou desembarcado na dita ilha "Antilia ou de São Brandão». Assim, em 1525, marinheiros portugueses afirmaram que, indo de Lisboa para a Palma, desembarcaram nesta ilha para consertar o navio, a qual referenciaram a 220 milhas da Palma, na quarta entre o poente e o oes-noroeste. Entusiasmados com esta notícia, os palmenses Fernando Tróia e Fernando Álvares partiram em sua busca, mas, tendo navegado durante alguns dias na direção que lhes tinha sido indicada, voltaram a casa sem jamais terem avistado tal ilha (Silva, 1999: 201-202).

Em 1550, o português Roque Nunes, juntamente com dois filhos seus e com o padre Martinho Aranha, partiu da Palma à descoberta da dita ilha e afirmou tê-la avistado.
Porém, tendo surgido entre o padre Martinho e Roque Nunes a dúvida sobre qual dos dois deveria desembarcar primeiro, e não se tendo chegado a acordo, regressaram à Palma sem terem concluído os seus objetivos (Silva, 1999: 202-203). No mesmo ano, o franciscano frei Bartolomeu Casanova, ao passar da Palma a Tenerife e estando em frente da Ponta de Teno, afirmou ter avistado a ilha de São Brandão. Se nos restantes casos Torriani não põe em causa a veracidade das informações, neste adverte ser impossível a referida ilha ser avistada daquela posição, estando à distância de mais de 300 milhas, por ficar encoberta pela curvatura das águas, não deixando porém de registar o facto (Silva, 1999: 203).

Segundo informações que Torriani diz terem-lhe sido prestadas por Pedro de Medina, sacristão-mor da Catedral de Canária, um fidalgo espanhol, chamado Zaballos, afirmara ter 
estado na ilha de São Brandão várias vezes, em 1554 e em anos anteriores, na última das quais nela substituiu os mastros do seu navio. A ilha tinha espessos bosques, onde viviam muitíssimas aves de tanta simplicidade que se deixavam apanhar à mão. Na grande e belíssima praia vira rasto de gigantes, pedaços de tijolos, pratos vidrados e fumo à distância (Silva, 1999: 202).

Em 1560, arribou à Palma, com tempestade, um navio francês, cujos marinheiros referiram terem estado nessa ilha, na qual tinham feito o mastro do navio. Acrescentaram terem deixado ali uma cruz grande, juntamente com uma carta e algumas moedas de prata, afirmando igualmente que a dita ilha não distaria da Palma «mais que a navegação de um dia e uma noite (Silva, 1999: 203). No ano seguinte, saindo da Palma, Fernando de Vilalobos foi com outros procurar a misteriosa ilha e, «tendo navegado alguns dias sem que a tenha avis- tado, voltou a casa com a trombeta no saco» (Silva, 1999: 204).

\section{Madeira e Porto Santo - Dos mitos à realidade}

No que respeita ao Porto Santo, Torriani apoia-se em Cadamosto, mas atualiza certos dados, ao registar que «a vila tem trezentos fogos e jaz sobre o porto, e por toda a ilha não há outra povoação, salvo algumas casas de lavradores». Acrescenta que «é plana, exceto que, sobre o porto, tem um morro de tão difícil acesso que serve para a retirada das gentes, quando se suspeita de inimigos». Diz ainda que «tem pouquíssimas águas e quase salgadas e, quando faltam as chuvas, é estéril e de pouco fruto, porque, em nossos dias, não se colhe nela outra coisa que trigo, que a basta, e uvas que, por serem tão poucas, não se faz vinho» (Fig. 9). Porto Santo, na voz inconfundível de Max - acrescentamos nós -, «És a jóia mais antiga das jóias de Portugal»! 


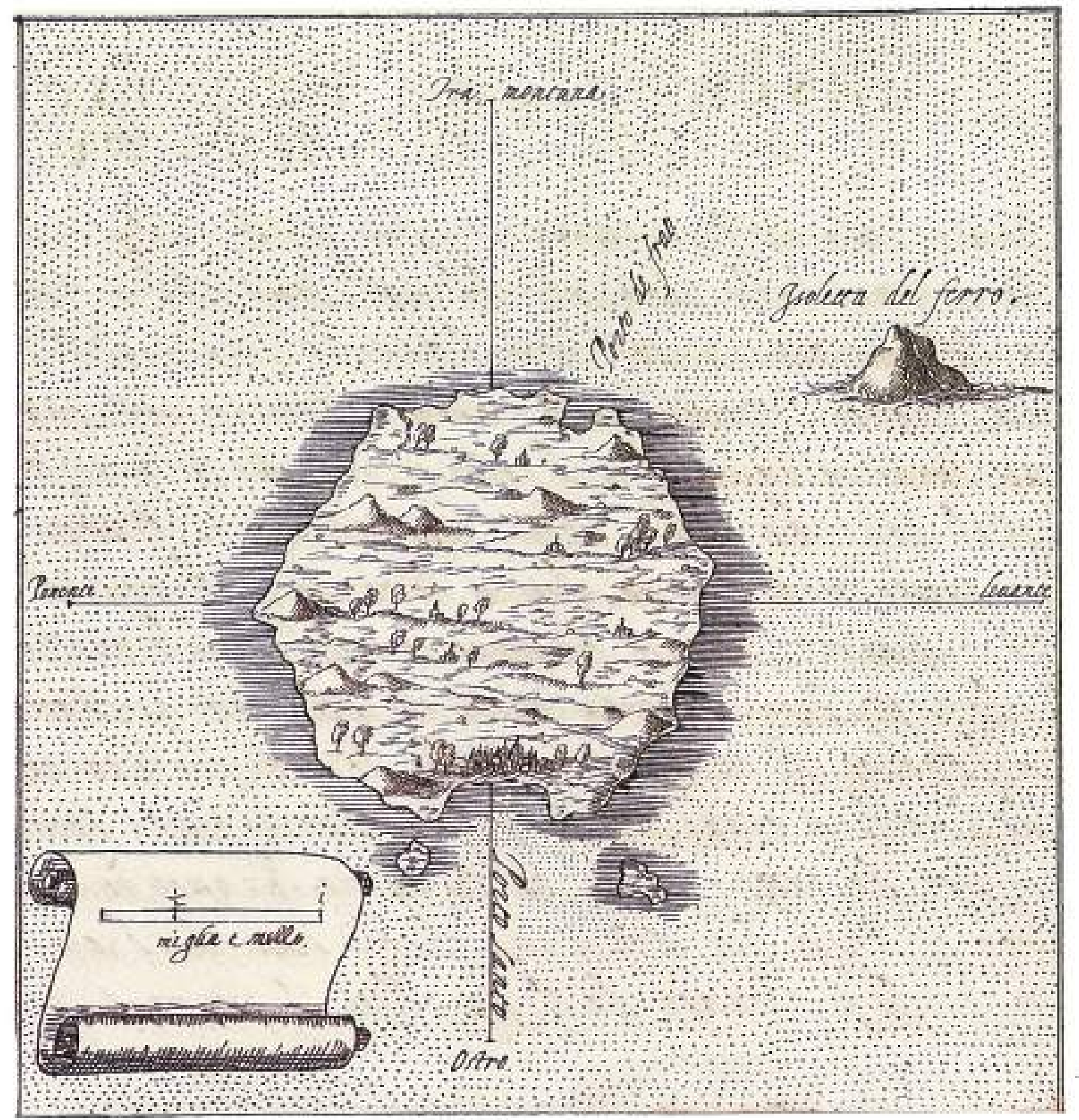

Fig. 9 - Mapa da ilha do Porto Santo.

Quanto à ilha da Madeira, depois de transcrever a descrição de Cadamosto, diz que «é áspera e montuosa, à imagem da Palma, mas tão cheia de infinitas ribeiras que, com elas e com a força da antiga fertilidade da terra e da indústria dos habitantes, tornou-se a mais bela, rica e povoada ilha de todas quantas, da Inglaterra para cá, se encontram neste mar» (Fig. 10). 

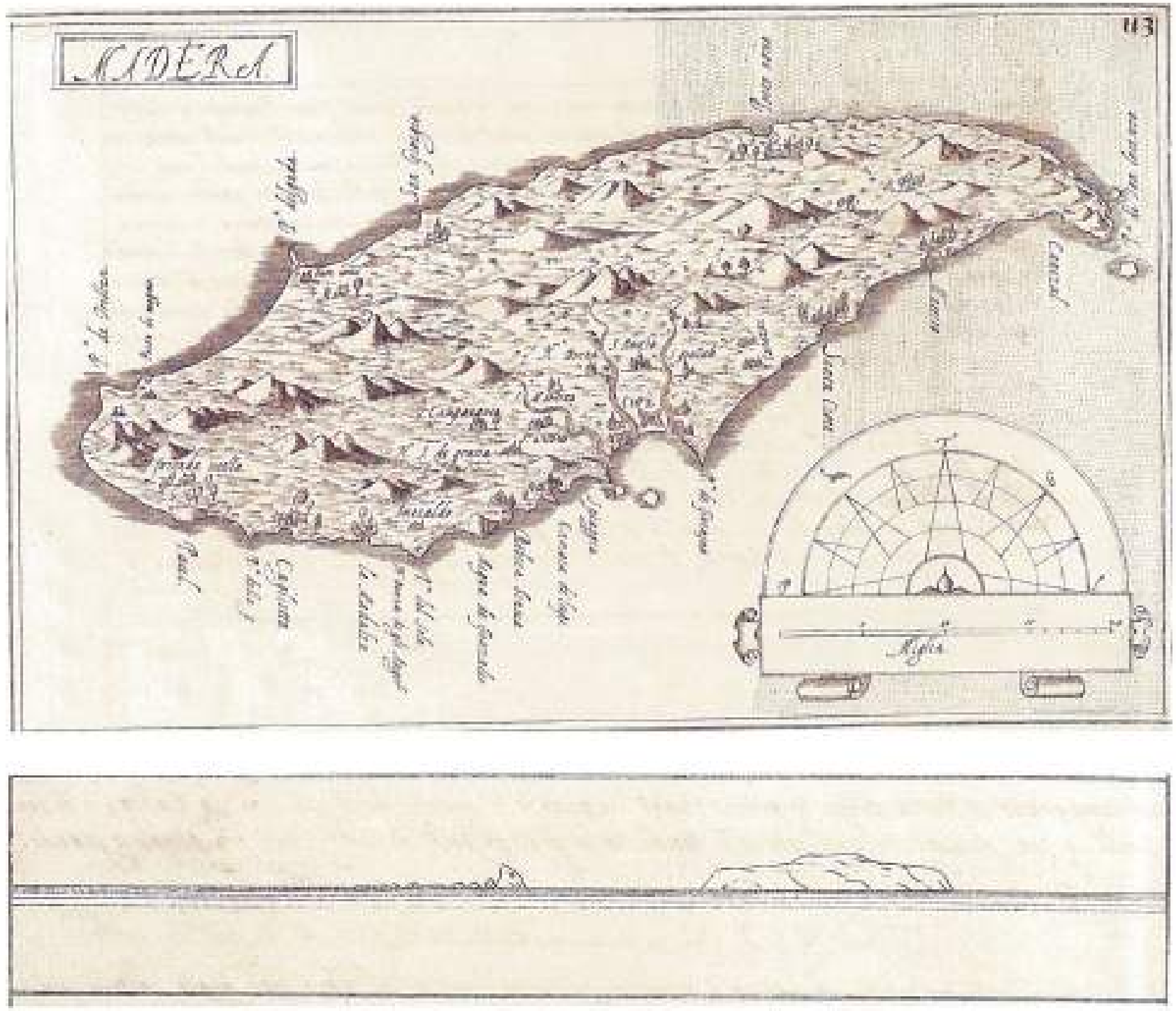

Fig. 10 - Mapa da ilha da Madeira e perfil das Desertas e das Selvagens.

Referindo-se à cidade do Funchal, diz que foi assim chamada «pelos funchos de que o dito lugar estava cheio, antes de ser edificada». Afirma ainda que, pelo importante comércio externo feito em navios que vêm das partes da África dos cristãos, da Itália, da Espanha, da França, da Alemanha e da Escócia, é chamada pelos mercadores «Pequena Lisboa». Realça que a ilha «produz muitíssimos açúcares e os melhores do Mundo e vinhos em abundância».
Regista a demografia da Madeira, nos finais do século XVI, com os seguintes dados: a cidade do Funchal tinha 2500 fogos; Machico, 200; Santa Cruz, 300; Caniço, 200; as paróquias de São Gonçalo, São Roque, Nossa Senhora, São Martinho, Santo António, Campanário e Nossa Senhora da Graça, 50 a 60 fogos cada uma; Calheta, 300; e todas as outras aldeias eram mais pequenas.

No que diz respeito à defesa da Madeira, refere que «agora atinge nove mil homens de guerra, 
sem contar três companhias de soldados castelhanos que el-rei ${ }^{5}$ ali tem para guarda da fortaleza da cidade».

Estranhamente, não se refere às ilhas Desertas.

\section{As Selvagens}

\section{e a costa da Berberia}

As Selvagens são duas ilhotas situadas, segundo Torriani, a «80 milhas das Canárias, a 150 da Madeira e a 300 da Berberia». Têm muitas e «grandes aves marinhas e de coelhos». Na verdade, se as Selvagens, geograficamente, fazem parte das Canárias, politicamente estão integradas no arquipélago da Madeira, nas quais, no tempo de Torriani, os nossos povoadores já tinham introduzido «muitos coelhos».

Quanto à costa da Berberia, escreve o nosso autor que «está frente ao mar das Canárias, entre os Montes Atlas, é despovoada, baixa, arenosa melancólica e cheia de moitas». Ali crescem «tamargueiras e anafis que é uma espécie de árvores que produz certos grãos vermelhos, pequenos... os quais os mouros comem. Tem cevada e pouco trigo, porque estes bárbaros não são dados à agricultura».

\section{Bibliografia}

\section{Manuscrita}

Biblioteca Geral da Universidade de Coimbra, Secção de Reservados, Leonardo Torriani, Códice 314. Descrittione et historia del regno de l'isole Canarie gia dette le Fortunate com il parere delle loro fortificatione.

\section{Impressa}

Barros, J. (1945). Ásia - Década I. (6. a ed., atualizada e anotada por Hernâni Cidade e Manuel Múrias). Agência Geral das Colónias. Lisboa;

Boémia, M. (1597). Relato do descobrimento da Guiné e das ilhas. Feito por Diogo Gomes, publicado por Valentim Fernandes, em versão latina, sob o título De prima inventione Guine. S. n.S. L.;

Camp, L. (s.d.). Continentes perdidos. A Atlântida, na história, na ciência e na literatura. Livros do Brasil. Lisboa;

Cortesão,A. e Mota,A. (1960). Portugalia monumenta cartographica. Comissão para as Comemorações do V Centenário da Morte do Infante D. Henrique. Lisboa. 6 vols.;

Ferreira, I. (1999). Mitos e utopias na descoberta e construção do mundo atlântico. Centro de Estudos de História do Atlântico. Funchal;

Frutuoso, G. (1873). Saudades da terra. História das ilhas do Porto Santo, Madeira, Desertas e Selvagens (anotado por Álvaro Rodrigues de Azevedo). Typographia Funchalense. Funchal. Livro II;

Galvão, A. (1987). Tratado dos Descobrimentos. (4. ${ }^{a}$ ed.) (reprodução diplomática, com versão atualizada por César Pegado, com estudo biobibliográfico, anotada e comentada pelo visconde de Lagoa, com colaboração de Elaine Sanceau). Livraria Civilização. Porto;

Godinho, V. (1990). Mito e mercadoria, utopia e prática de navegar. Séculos XIII-XVIII. Difel Difusão Editorial, L. ${ }^{\text {da }}$. Lisboa;

${ }^{5}$ Filipe II de Espanha, Filipe I de Portugal. 
Grimal, P. (1951). Dicionário da mitologia grega e latina. Difel - Difusão Editorial, L.da. Lisboa; Marques, J. (Dir.) (1944-1971). Descobrimentos portugueses. Documentos para a sua história. Instituto de Alta Cultura. Lisboa. 3 vols.;

Mieiro, E. (2001). A atlantização mítica do Éden. Novos mundos, novos paraísos. Centro de Estudos de História do Attântico. Funchal;

Silva, J. (1995). A Madeira e a construção do mundo atlântico (séculos XV-XVII). Centro de
Estudos de História do Atlântico/Secretaria Regional do Turismo. Funchal. 2 vols.;

Silva, J. (Ed. e Trad.) (1999). Descrição e história do reino das ilhas Canárias, de Leonardo Torriani. Edições Cosmos. Lisboa;

Silva, J. (2021). Portugal, segundo a Beira Alta. Theya Editores. Lisboa;

Tasso, T. (1590). Gerusalemme liberata. S. n. Génova. 